\title{
THE ETIOLOGICAL FACTOR FOR EOSINOPHILIA AND HYPERGLOBULINEMIA E IN BRAZILIAN SCHOOL CHILDREN
}

\author{
Atsuo Hamada ${ }^{1}$, NaOHiro WATANABE ${ }^{1}$, Masashi Kobayashi ${ }^{2}$, \\ EIICHI OKUSAWA ${ }^{3}$, TOMOYOSHI NOZAKI ${ }^{3}$, Ivete BARBOSA ${ }^{4}$, \\ Seiki TATENO ${ }^{4}$ AND AKIO Kobayashi ${ }^{1}$ \\ Received March 5 1991/Accepted April 101991
}

\begin{abstract}
The etiology of peripheral blood eosinophilia and hyperglobulinemia E, which are commonly found among residents in tropical area, were studied with two groups of Brazilian children from different primary schools. These two groups of children had different infection rates with soil-transmitted helminthiases, but similar positive rates of antibody against a common allergic antigen. The prevalence rate of children with eosinophilia or hyperglobulinemia E was significantly higher in a group with higher infection rate with soil-transmitted helminthiases than in another group with lower infection rate. It was suggested that eosinophilia and hyperglobulinemia $\mathrm{E}$ in this area were mainly caused by soil-transmitted helminthiases.
\end{abstract}

\section{INTRODUCTION}

Peripheral blood eosinophilia and hyperglobulinemia E (hyperIgE) are common laboratory findings among residents in tropical areas (Johansson et al., 1968; Mahmoud, 1984). It has been empirically supposed that these abnormal findings are caused by helminth infections, which are major health problem in tropical areas. However, the comparisons in the number of eosinophils and serum IgE level between helminth infected and uninfected subjects in one community usually failed to show prominent differences (Bruce-Tagoe et al., 1977; Kaplan et al., 1980).

Allergic diseases are another etiological factor for eosinophilia and hyperIgE especially in residents in temperate areas. It has been demonstrated that the morbidity of allergic diseases was not so low even in tropical residents (Lynch et al., 1984). Therefore the participation of allergic diseases on eosinophilia and hyperIgE in tropical residents also

1 Department of Parasitology, Jikei University School of Medicine, Japan.

2 Department of Parasitology, School of Medicine, Chiba University, Japan.

3 Department of Parasitology, School of Medicine, Keio University, Japan.

4 Laboratorio de Imunopatologia Prof. Keizo Asami, Universidade Federal de Pernambuco, Brazil.

This study was supported in part by the Japan International Cooperation Agency, and grant-in-aid for scientific research (No. 0277027) from the Ministry of Education, Science and Culture of Japan. Address reprint request to Atsuo Hamada, M.D. Department of Parasitology, Jikei University School of Medicine, 3-25-8 Nishishinbashi, Minato-ku, Tokyo 105, Japan. 
should be considered.

To know the etiology of eosinophilia and hyper IgE in tropical residents, we examined the number of eosinophils and serum IgE level in two groups of Brazilian children living in a city, in relation to soil-transmitted helminthiases and allergic diseases.

\section{METHODS}

\section{Participants}

Recife, located in the northern part of Brazil, is a port city with a population of one million. Two primary school in Recife were chosen for testing. One in Varzea (VAR) located in the suburbs, where sanitary condition is poor. The other in Madalena (MAD) is in the center of the city with good sanitation. The stool and peripheral blood were collected from 92 school children in VAR and 18 school children in MAD (age range from 6 to 12 years old).

Stool

Fecal samples were collected and examined for helminth eggs by modified Kato-Katz method.

\section{Blood}

The number of eosinophils was microscopically counted with Hinkelman's staining. The presence of eosinophils more than $500 / \mathrm{mm}^{3}$ was considered as eosinophilia. Serum IgE level were measured by using Phadezym IgE PRIST kits (Pharmacia fine chemicals) and were expressed as international units per $\mathrm{m} l(\mathrm{IU} / \mathrm{m} l)$. HyperIgE was defined as serum IgE level more than $500 \mathrm{IU} / \mathrm{ml}$. The level of anti-house dust $\mathrm{IgE}$ antibody was determined by Radio Allergo Sorbent Test (Pharmacia fine chemicals). Scores higher than 2 were considered as positive.

Statistical analysis

Data were analysed by the application of $\chi^{2}$ test or student's t test.

\section{RESULTS}

\section{Stool examination}

Results of the stool examination are shown in Table 1. Fifty eight (63\%) of 92 children

Table 1 Results of stool examinations among school children in Recife, Brazil

\begin{tabular}{lcccc}
\hline & \multicolumn{4}{c}{ No. $(\%)$ children positive for } \\
\cline { 2 - 5 } & helminth eggs & A.l. & T.t. & A.l. \& T.t. \\
\hline $\begin{array}{c}\text { School in VAR } \\
(\mathrm{N}=92)\end{array}$ & $58(63 \%)^{*}$ & 19 & 20 & 19 \\
$\begin{array}{c}\text { School in MAD } \\
(\mathrm{N}=18)\end{array}$ & $1 \quad(6 \%)$ & 0 & 1 & 0 \\
\hline
\end{tabular}

A.1.: Ascaris lumbricoides, T.t.: Trichuris trichiura

* This percentage was significantly higher than that of school in MAD $(\mathrm{p}<0.001)$. 
Table 2 Number of eosinophils and serum IgE level among primary school children in Recife, Brazil

\begin{tabular}{lccc}
\hline & $\begin{array}{c}\text { School in VAR } \\
(\mathrm{N}=92)\end{array}$ & $\begin{array}{c}\text { School in MAD } \\
(\mathrm{N}=18)\end{array}$ & $\mathrm{P}^{\S}$ \\
\hline $\begin{array}{l}\text { No. eosinophils* } \\
\left(/ \mathrm{mm}^{3}\right)\end{array}$ & $1,053 \pm 80$ & $317 \pm 51$ & \\
$\begin{array}{l}\text { No. } \%) \text { children } \\
\text { with eosinophila }\end{array}$ & $66(72 \%)$ & $3(17 \%)$ & $<0.001$ \\
$\begin{array}{l}\text { Serum IgE level } \\
(\mathrm{IU} / \mathrm{m} l)\end{array}$ & $1,202 \pm 114$ & $525 \pm 175$ & \\
$\begin{array}{l}\text { No. }(\%) \text { children } \\
\text { with hyperIgE }\end{array}$ & $67(73 \%)$ & $5(28 \%)$ & $<0.001$ \\
\hline
\end{tabular}

\footnotetext{
* Number indicate mean \pm SEM.

$\dagger$ Number of eosinphils more than $500 / \mathrm{mm}^{3}$.

$\ddagger$ Serum IgE level more than $500 \mathrm{IU} / \mathrm{m} l$.

$\S \mathrm{P}$ value calculated from the percentages.
}

in VAR were found to be positive for helminth eggs (Ascaris lumbricoides alone, 19; Trichuris trichiura alone, 20; Both, 19). Of the 18 children in MAD, only one $(6 \%)$ was positive for helminth eggs. The prevalence rate of soil-transmitted helminthiases were significantly higher in VAR children than in MAD children $(\mathrm{P}<0.001)$.

Anti-house dust IgE

As a marker of allergic diseases, antihouse dust IgE antibody was measured in 32 children in VAR and 18 children in MAD. Only 3 (9\%) and 2 (11\%) students were positive in VAR and MAD children, respectively. Therefore, with respect to the prevalence of anti-house dust IgE antibody, no significant difference was observed between these two groups.

Number of eosinophils and IgE level

Prominent increase of the mean number of eosinophils and serum IgE level were observed in the children of VAR (eosinophils: $1,053 \pm 80 / \mathrm{mm}^{3}$, IgE: $1,202 \pm 114 \mathrm{IU} / \mathrm{m} l$ ) (Table 2). The percentage of children with eosinophilia (eosinophils $>500 / \mathrm{mm}^{3}$ ) was $72 \%$, and children with hyperIgE ( $\operatorname{IgE}>500$ $\mathrm{IU} / \mathrm{m} l$ ) was $73 \%$. Significant correlation was

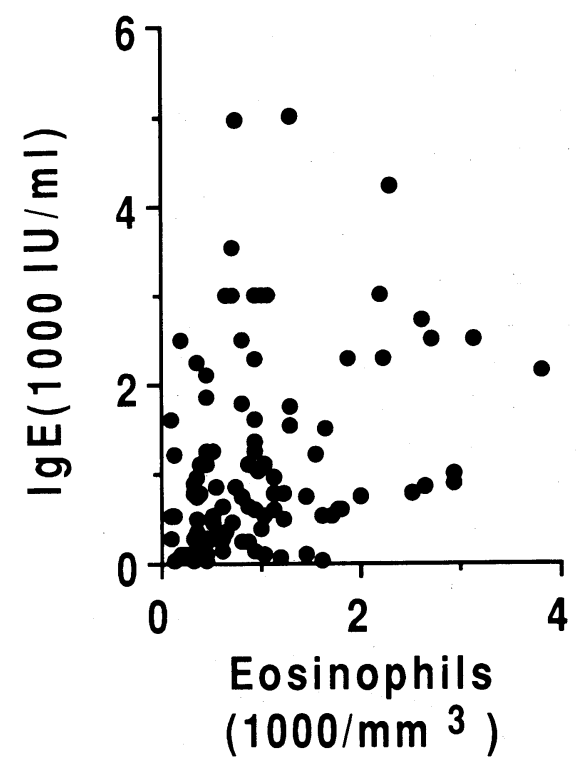

Figure 1 Correlation of the number of eosinophils and serum IgE level in primary school children in VAR. The number of eosinophils showed a significant correlation with serum IgE level $(r=0.24314, p<0.05)$. 
demonstrated between the number of eosinophis and $\operatorname{IgE}$ level $(\mathrm{p}<0.05$, Figure 1$)$. Therefore, it is supposed that frequently observed eosinophilia and hyperIgE in VAR children were caused by the same etiology, such as soil-transmitted helminthiases.

On the other hands, in MAD children, the mean number of eosinophils and serum IgE level were nearly normal values (eosinophils: $317 \pm 51 \mathrm{~mm}^{3}$, IgE: $525 \pm 175 \mathrm{IU} / \mathrm{ml}$ ) (Table 2). The percentage of children with eosinophilia was $17 \%$ and, children with hyperIgE was $28 \%$. When percentages of children with eosinophilia were compared between VAR and MAD children, significantly higher percentage was observed in VAR than in MAD $(P<0.001)$. Similarly, the percentage of children with hyperIgE was significantly higher in VAR than in MAD $(\mathrm{P}<0.001)$.

\section{Discussion}

Eosinophilia and hyperIgE has been known to occur in association with helminth infections or allergic diseases (Bennich and Johansson, 1971; Gleich and Adolphson, 1986). Many previous studies demonstrated that eosinophilia and hyperIgE were common in communities with high prevalence of helminth infections (Johansson et al., 1968; Mahmoud, 1984). However, it has been also reported that the number of eosinophils and serum IgE level were not significantly different between helminth infections positive and negative subjects within a community (Bruce-Tagoe et al., 1975; Kaplan et al., 1980).

In the present study, eosinophilia and hyperIgE were frequently found in VAR children compared with MAD children. The difference between these two communities was also apparent in regard to the rate of helminthic infections. These results strongly suggest that eosinophilia and hyperIgE in VAR children were caused by soil-transmitted helminthiases.

These two schools were located in the same city, and race and life style of the children was almost the same. The recent epidemics of schistosomiasis and filariasis were not found in this city (Dr. Ivete Barbosa, personal communication), suggesting that helminth infections other than soil-transmitted may be excluded from the etiology for eosinophilia and hyperIgE.

It has been reported that the incidence of allergic diseases in tropical area is identical to those in temperate area, especially in urban district (Lynch et al., 1984). Anti-house dust IgE antibody was chosen as a marker of allergic diseases in this study, since house dust antigen is the most popular allergen in tropical residents (Lynch et al., 1984). The prevalence rates of anti-house dust IgE antibodies were almost the same in children of both VAR and MAD, suggesting that allergic diseases were not involved in the major etiologies for eosinophilia and hyperIgE in VAR children.

The number of eosinophils and serum IgE level in VAR children were significantly correlated. Therefore, it is likely that infected helminths concurrently caused eosinophilia and hyperIgE. Helminthic infections preferentially induce one of the subsets of helper $\mathrm{T}$ lymphocytes (TH2), which produce both interleukin-4 (IL-4) and interleukin-5 (IL-5) (Mosmann and Coffman, 1989). These lymphokines have the function to elicit coincidently hyperIgE and eosinophilia, namely IL-4 accelerates B lymphocytes to secrete IgE (Stavnezer et al., 1988), and IL-5 promote proliferation of eosinophils in bone marrow (Coffman et al., 1989). It is also possible that IgE antibody, produced by stimulations with helminths, subsequently gives signals to mast cells to release eosinophil chemotactic factor which cause eosinophilia. 
Additional investigation into the precise mechanisms for eosinophilia and hyperIgE in these patients with soil-transmitted helminthiases is needed.

\section{ACKNOWLEDGEMENT}

The authors wish to thank Ms. Iran Duarte and Mr. Amaro Cosme for their technical assistance.

\section{REFERENCES}

1) Bennich, H. and Johansson, S.G.O. (1971): Structure and function of human immunoglobulin E, Adv. Immunol., 13, 1-55

2 ) Bruce-Tagoe, A.A., Belcher, D.W., Wurapa, F.K., Turkson, P., Nicholas, D.D. and OfosuAmaah, S. (1977): Hematological values in a rural Ghanaian population, Trop. geogr. Med., 29, 237-244

3 ) Coffman, R.L., Seymour, B.W.P., Hudak, S., Jackson, J. and Rennick, D. (1989): Antibody to interleukin-5 inhibits helminth-induced eosinophilia in mice, Science, 245, 308-310

4 ) Gleich, G.L. and Adolphson, C.R. (1986): The eosinophilic leukocyte: Structure and function, Adv. Immunol., 39, 177-253

5 ) Johansson, S.G.O., Mellbin, T. and Vahlquist, B. (1968): Immunoglobulin levels in Ethiopian preschool children with special reference to high concentrations of immunoglobulin E (IgND), Lancet, 1, 1118-1121

6 ) Kaplan, J.E., Larrick, J.W. and Yost, J.A. (1980): Hyperimmunoglobulinemia E in the Waorani, an isolated amerindian populatipon, Am. J. Trop. Med. Hyg., 29, 1012-1017

7 ) Lynch, N.R., Medouze, L., DiPrisco-Fuenmayor, M.C., Verde, O., Lopez, R.I. and Malave, C. (1984): Incidence of atopic disease in a tropical environment: Partial independence from intestinal helminthiasis, J. Allergy Clin. Immunol., 73, 229-233

8 ) Mahmoud, A.A.F. (1984): Tropical and Geographic Medicine, 70-75 McGraw-Hill, New York

9 ) Mosmann, T.R. and Coffman, R.L. (1989): TH1 and TH2 cells: different patterns of lymphokine secretion lead to different functional properties, Annu. Rev. Immunol. 7, 145-173

10) Stavenzer, J., Radcliffe, G., Lin, U.C., Nietupski, J., Berggren, L., Sitia, R. and Severinson, E. (1988): Immunoglobulin heavy-chain switching may be directed by prior induction of transcripts from constant-region genes, Proc. Natl. Acad. Sci. USA, 85, 7704-7708 
ブラジル, レシフェ市内小学生の好酸球増多症, 高 $\operatorname{IgE}$ 血症の病因

浜田 篤郎 ${ }^{1} \cdot$ 渡辺 直熙 1 小林 仁 $^{2} \cdot$ 奥沢 英一 $^{3}$

野崎 智義 ${ }^{3} \cdot$ Ivete Barbosa $^{4}$ ・建野 正毅 ${ }^{4}$ 小林 昭夫 1

熱带地住民に高率にみられる好酸球增多症および高 $\operatorname{IgE}$ 血症の病因を究明するため, ブラジ ル, レシフェ市内の 2 つの小学校生徒を対象に, 未梢血好酸球数, 血清総 $\operatorname{IgE}$ 值を測定した。ま た, 蠕虫感染の指標として䔬便内蠕虾卵検査, アトピー性疾患の指標として血清抗ハウスダスト $\mathrm{IgE}$ 抗体価の測定を施行した。2 校の生徒間で，抗ハウスダスト IgE 抗体陽性率には差がなかっ たが, 翼便内蠕虫卵陽性率には著明な差を認めた。検出された虫卵は, 全て土壌伝播蠕虫卵であっ た。好酸球增多症 (好酸球数 $500 / \mathrm{mm}^{3}$ 以上), 高 $\mathrm{IgE}$ 血症 ( $\mathrm{IgE}$ 值 $500 \mathrm{IU} / \mathrm{m} l$ 以上) を呈する生徒 は，䔬便内蠕虫卵陽性率が高い小学校において，有意に高率㳊認められた。

以上から,この地方における小学生の好酸球增多症および高 $\operatorname{IgE}$ 血症の病因として, 土睢伝播 蠕虫感染が考元られた。

1 東京慈恵会医科大学寄生虫学教室

2 千葉大学医学部寄生虫学教室

3 慶応大学医学部寄生虫学教室

4 浅見敬三兔疫病理センター 